\title{
Founding Fathers, Turtles and the Elephant in the Room: The Quest for Origins in the Scientific Study of Religion ${ }^{1}$
}

\author{
INGVILD SÆLID GILHUS \\ University of Bergen
}

\begin{abstract}
The theme of the present article is the quest for origins, founding fathers and the never-ending search for identity in the scientific study of religion. Because the quest for origins and for founding fathers is intertwined with the complex relationship to theology, theology is frequently made into the significant other. The elephant is a metaphor for the preoccupation with theology. The article discusses the longing for origins, and it discusses good fathers and bad fathers, and especially Max Müller's contribution to the study of religion. It also takes up the new quest for historical origins as well as the quest for generative mechanisms of religion and asks why the study of religion needs the metaphysical boosts of origins. A permanent preoccupation with universal patterns in the study of religion, recent developments in science, contemporary processes of globalization, a renewed general interest in religion, a wish to control the field and the continuous struggle to be different from theology are pointed out as reasons for the never-ending quest for origins. The article suggests that it might be fruitful to let go of the preoccupation with theology, and further that grand-scale comparative studies and universal claims need to be matched by small-scale studies of religion on the ground and by embracing complexity and reflexivity.
\end{abstract}

Keywords: origins, founding fathers, Max Müller, theology, history, cognitive science, study of religion

Origins constitute an important category in intellectual debate, because they provide a defining site for essence and truth, and empower those who control it. Origin describes the moment when something begins and gives it consequentiality. ${ }^{2}$ Origin can mean both cause and source; these meanings

1 The author wants to thank Professor Lisbeth Mikaelsson for reading and commenting on an earlier version of this article.

2 Origo, from the root: oriri 'to rise', is Latin and means 'beginning, source, birth, origin'. 
are often fused (cf. Preus 1987, ix). ${ }^{3}$ When Sigmund Freud in his Totem und Tabu describes the brothers who killed and devoured their father, the motif points to a moment in time, a beginning, as well as to a general mechanism that generates religion, culture and civilization - a mechanism that is both cause and source.

Beginnings should be examined as part of narrative, as Aristotle did. ${ }^{4}$ This implies that new beginnings can always be constructed behind old ones. An important function of presenting an older and more spectacular beginning is to make its supporters more powerful than their opponents. Beginnings and ends are strong instruments, because they give meaning and direction to narratives, not only to religious narratives, but to historiography and research history as well. When and where does the history of religions begin? According to Daniel Lord Smail in Deep History and the Brain, it usually begins in Mesopotamia, because we are still in the grip of sacred history and dependent on the Bible and holy writ (Smail 2009). Deep history, in comparison, delves into the pre-history of the human past, while Big History goes the whole hog back to the Big Bang itself and is hard to trump.

There is more generally an underlying assumption that religions are distinct entities with origins, and frequently also with founders. ${ }^{5}$ The hunt for origins may obscure complexity and end with oversimplification, which is the case with the idea of the 'Abrahamic religion'. This concept points to

3 In addition to biogenetic and historio-genetic theories, there are sociogenetic and psychogenetic theories about origin as well - psychological or sociological origin is 'conditions characteristic of human life in all times and places' (Pals 2006, 308). It is further helpful to make a distinction between historic beginnings and a-historic origins, as Jonathan Z. Smith did (McCuthcheon 2001, 198, note 6).

4 In his Poetics, Aristotle launched the idea that, 'a whole is what has a beginning and middle and end' (1450 b 28). And he adds, 'A beginning is that which is not a necessary consequent of anything else but after which something else exists or happens as a natural result' (1450 b 28).

5 Did Christianity begin with Jesus or with Paul or did it begin later? Did Christianity have a multiple origin? When did the ways of Judaism and Christianity part? Eusebius, for instance, introduces his history of Christianity with the beginning of time. The religious picture in late antiquity was in addition much more complex than what the hunt for origins and the creation of distinct genealogies reflect. Epiphanius, bishop of Salamis (Constantia) on Cyprus, describes the religious situation at the end of the fourth century in this way: 'Even today, in fact, people call all the sects, I mean Manichaeans, Marcionites, Gnostics and others, by the common name of "Christians", though they are not Christians' $(29,6,6)$. Here the view from the common people is countered by how theologians wished it should be. Ancient religions lived on in Christianity or, put in another way, Christianity can be seen as a more general transformation of religions in antiquity with its Eucharistic sacrifices, initiations and sacred texts. The hunt for origins may obscure complexity and end with oversimplifications. 
a common ancestry for Judaism, Christianity and Islam, but in doing so, conceals the differences between the three religions. ${ }^{6}$

The theme of the present article is the quest for origins, founding fathers and the never-ending search for identity in the scientific study of religion. Because the quest for origins and for founding fathers is intertwined with the complex relationship to theology, theology is frequently made into the significant other. It gives the scientific study of religion an identity, very much in line with Michel de Certeau's words: 'I am other than I would wish to be, and I am determined by what I deny' $(1988,46)$. Theology is committed to its religious fundamentals, which the study of religion emphatically is not. When the title of the article points to the elephant in the room, the intention is not to suggest that theology usually goes unaddressed. Rather, there is sometimes in study of religion circles a preoccupation with theology, which finds its outlet in a continuous struggle to establish and maintain difference. Sometimes this preoccupation is very clearly stated: 'Religion - and the study thereof - requires Theology for its cogency, just as the field or discipline of Religious Studies continues to require the existence of Theology as an amorphous Other against which to establish an otherwise indeterminate identity' (Arnal \& Braun 2012, 232). ${ }^{7}$ Not so clear, however, is the effect of the preoccupation with theology on the discipline and how much space the struggle takes. ${ }^{8}$ This is the elephant in the room, not theology as such. It seems that the scientific study of religion always has and probably always will have (though hopefully not!) the theological study of religion as its significant other. ${ }^{9}$

The turtles point to the infinite regress problem in cosmologies - a problem which is sometimes caught by the jocular expression, 'there are turtles all the way down'. Here the turtles stand for ancestors, venerable and not

\footnotetext{
6 Aaron W. Hughes has recently pointed out that the 'Abrahamic religions' discourse, which presupposes a common ancestor of the three Western monotheistic religions, 'has created a nebulous category within which Judaism, Christianity, and Islam sit, often uncomfortably, with one another' (Hughes 2012, 141).

7 According to Arnal and Braun, what we call religion is, rather ironically 'the object that devotees have identified as sacred' (Arnal \& Braun 2012, 231). This means, in their view, that our manner of classifying things is basically theological (ibid. 233). "Religion" itself as a framework, a category, and thus as a demarcation for a non-theological discipline (Religious Studies) is defined precisely by its theological content' (Arnal and Barun 2012, 231).

8 In this article, the study of religion is treated as a discipline. It is, however, a debated question whether it is a field or a discipline (see Stausberg 2007, 303, note 21; Sutcliffe 2008, 107). 9 In practice, the relationship to theology has, of course, been complex. It has both been a competition about the position and allocation of resources at the universities as well as disciplinary differences, and it is difficult to keep these things separate from each other.
} 
so venerable, and refer to the long genealogies that are present in a research history. These genealogies reach further back than the 1870s, when the first chairs in a non-theological study of religion were established at universities: 'Questions as to what religion is and why different people practice it as they do doubtless reach back as far as the human race itself' (Pals 2006, 4).

Michel Foucault proposes that what 'is found at the historical beginning of things is not the inviolable identity of their origin: it is the dissension of other things. It is disparity' (Foucault 1980, 142). Foucault quotes Nietzsche when he says that the 'lofty origin is no more than "a metaphysical extension, which arises from the belief that things are most precious and essential at the moment of birth"' (ibid. 143). Instead of beginnings, there are multiple origins. Genealogies can sometimes be deconstructed à la Nietzsche or à la Foucault, and sometimes used as the means to create venerable ancestors and new identities, as suggested by Hayden White (cf. Paul 2011, 171). The creation of origins is made by choice and for a purpose, which makes us ask: What is the function of founding fathers? How much do we need them? Why is the quest for origins so prominent in the study of religion? And, if the quest for origins is closely connected to the preoccupation with theology, what is gained by letting this preoccupation go?

\section{Good Fathers and Bad Fathers}

Hayden White suggests that in the quest for disciplinary history we choose 'a fictional cultural ancestry' and create a sort of myth of the origin of the discipline, and 'in choosing a past, we choose a present, and vice versa. We use the one to justify the other.' (White 1972, 235-6.) Research history is among other things a genre for selecting venerable ancestors, and by means of these, articulating an identity. ${ }^{10}$ This is closely connected to how scientific fields are created by means of a professionalization process (White, 1973, 269, 276). In the attempt to create an ancestry for the scientific study of religion, some ancestors have been regarded as more venerable at the cost of others.

Since origin is an instrument of hierarchy and power, used to take control over events and define groups in relation to each other, it comes as no surprise that the champions of the new science of religion, or Religionswissenschaft, to use Friedrich Max Müller's term, tried to take control over the origins of religion. This was the quest of Max Müller, as well as of Edward

10 'Origins help articulate identities, and where communities locate their beginnings tells us quite a lot about how they perceive themselves', says the sociologist Eviatar Zerubavel $(2003,101)$. 
B. Tylor, James Frazer, Sigmund Freud and others. The task ahead was to create an identity different from theology. The belief in the divine origin of religion was replaced by the quest for a natural origin (cf. Pals 2008, 21).

In his book Explaining Religion: Criticism and Theory from Bodin to Freud (1987), J. Samuel Preus asks how nine Western thinkers have accounted for the 'natural' origin of religion. ${ }^{11}$ Preus detects 'a coherent research tradition' as well as 'a new paradigm for studying religion' (p. ix). He labels the paradigm 'naturalistic'. ${ }^{12}$ Preus argues that it was David Hume (1711-76) who really turned the corner and had 'a vision of religion as part of a science of humankind' (p. 100). Preus thus sees 'Hume as founder of the scientific study of religion' (p. 84, note 1), and the publication of Hume's Natural History of Religion (1757) as 'the achievement of a paradigmatic moment' (p.xv). Preus's book also asserts that this study of religion was not 'a recent bastard of theological studies, but a legitimate, truly academic area of study' (Tilley 1991, 242).

Eric Sharpe locates the beginning of the discipline he calls 'Comparative Religion' after Darwin's The Origin of the Species (Sharpe 1975). He sees Max Müller as the founding father, but like some others, he presents the Egyptologist Cornelis P. Tiele as the other serious contender for the title (Sharpe 1975, 35). In addition, Sharpe, like Preus, searches for antecedents - in this case, ancient antecedents. Sharpe mentions for instance Xenophanes, Herodotus, Chrysippus and the Stoics (who classified cults by means of their origin).

Let us for a moment pause at Max Müller. When all is said and done, more than anyone else it is Müller who is usually hailed as the founding father of the scientific study of religion. ${ }^{13}$ Sharpe, for instance, selects him for his advocacy of the new science (Sharpe 1975, 35). Was he a good father? Max Müller asked about the origin of religion, which he found in the perception of the infinite (Sharpe 1975, 38-9). He called attention to connections between meteorological phenomena and gods; he presented fascinating theories about how terms were turned into powers - nomina were transformed into numina; and he claimed that mythology appeared as 'a disease of language'. When they were first launched, his theories were heavily criticized. Today his books are seldom read and he is not much referred to, except as the

11 Jean Bodin, Herbert of Cherbury, Bernard Fontenelle, Gianbattista Vico, David Hume, Auguste Comte, Edward Burnett Tylor, Émile Durkheim and Sigmund Freud.

12 Preus saw the emergence of the naturalistic paradigm three hundred years before it became institutionalized by Tylor in Anthropology, by Durkheim in Sociology and by Freud in Psychoanalysis. See also Stausberg 2007, 298-300 ('Searching for the roots').

13 Tomoko Masuzawa notes that Max Müller has been honoured as the founder of comparative religion at least from the beginning of the twentieth century (Masuzawa 1993, 58-9). 
founder and father of a comparative study of religion. Tomako Masuzawa sees the new science of religion as something which Max Müller tended while he was doing something else - translating the Rig Veda and editing the Sacred Books of the East. Masuzawa has pointed out that Max Müller was a philologist and an expert in Indian languages, who offered only 'Chips from his German workshop' to the new discipline. In her words Max Müller 'happened to become famous for what was for him essentially a hobbyhorse: speculations on the origin of mythology and the growth of religion' (Masuzawa 1993, 8). This view is contested, however; Ivan Strenski labelled it a 'misreading of Max Müller' (1996), arguing that there was no disjunction between Max Müller's work on comparative philology and his work on religion and myth.

The ambiguity of the status of Max Müller is further revealed in the selection made by Daniel L. Pals in Eight Theories of Religion. ${ }^{14}$ In this boook, Max Müller is presented briefly in the Introduction, but Pals does not include his theories among those that matter, for as he rightfully remarks: 'Important as he was in promoting the idea of a science of religion, Max Müller has been left aside because his own theory, which found religion to originate in nature worship, was for the most part rejected in his own time and had only limited influence hereafter.' (Pals 2006, 12.) Nor does Samuel Preus cite Müller or include any of his books in his bibliography.

Siblings do not always agree on fathers and their importance. It is probably true to say that as long as the scientific study of religion was mainly a historical study based on ancient texts, Müller fitted the bill as an ideal and a founding father very well. And, perhaps more important for his fatherhood, Max Müller's often quoted maxim, 'He who knows one, knows none!' (Müller 1872, 1) is usually regarded as the 'words of creation' in a study that so desperately does not want to be the bastard son of a theological father-line. ${ }^{15}$ In the founding myth of this study, the struggle with theology is personified in the church historian Adolf von Harnack, who in his response to Müller pointed to Christianity: 'Whoever does not know this religion, knows none, and whoever knows Christianity together with its history, knows all religion' (Harnack 1906, 168). Max Müller and Adolf

14 The eight theories are those of E. B. Tylor and J. G. Frazer, Sigmund Freud, Émile Durkheim, Karl Marx, Max Weber, Mircea Eliade, E. E. Evans-Pritchard and Clifford Geertz (Pals 2006). An earlier edition of the book, Seven Theories of Religion, did not include Max Weber (Pals 1996). 15 Edward B. Tylor gave voice to a similar sentiment, 'for no more can he who understands but one religion understand even that religion, than the man who knows but one language can understand that language' (Tylor 1871, II, 5). 
von Harnack represent the good father versus the bad father, the father line of the scientific study of religion versus the rejected father line of theology.

A similar story of the origin of the secular study of religion can be found in Norway. Here in 1913 Wilhelm Schencke (1869-1946) characterized the Theological Faculty at the University of Oslo as the 'inflamed appendix' of the university and argued that it should be closed because of its commitments to theological values and norms (Tidens Tegn 1913). He was appointed to a professorship in the history of religions the year after - the first in Norway - and was moved from the Theological Faculty to the Faculty of Arts. Schencke's outburst is not of the same quality as Max Müller's maxim, but it marked the beginning of a secular study of religion in Norway (Gilhus \& Jacobsen 2014). Like Müller's 'He who knows one, knows none', Schencke's statement about theology as the inflamed appendix of the body of the university, best removed by surgery, are words of creation which point to the attempted break with theology as an important generative mechanism in the scientific study of religion.

The research paradigms of these origins, however, have little bearing on what the study of religion has subsequently been about. This study has in the main been dependent on other types of sources and approaches than those pursued by most of the founding fathers. In a way the research history and its heroes are connected to a field that looks very different from what one would have expected if it had been developed in accordance with their theories.

This is seen in Pals' Eight Theories of Religion, which includes nine scholars (Pals 2006). Six are from the social sciences (Tylor, Durkheim, Marx, Weber, Evans-Pritchard, Geertz) and one from medicine (Freud). Only two have their background in the humanities (Frazer and Eliade). Pals points out two common feature of these nine scholars: their defining of religion as in relation to superhuman beings, and the fact that they are not theologians, which is one of the prerequisites for including them. In other ways, their theories differ in most cases very much from each other.

Pals' choice of theoreticians illustrates a discrepancy between the research history and the current orientation of the study of religion. One factor is that this discipline has in the main been developed within the faculties of humanities or theology, not in the departments of social sciences. Another thing is that the research has only to a small degree concentrated on indigenous peoples and anthropological data, as more than half of the scholars in Pals' selection did. For most of the twentieth century, the new discipline mainly centred around historical studies, which were focussed 
on texts and were dependent on biblical scholarship, historical-philological methods, and later also on the developments in literary scholarship. The label of this study was in many cases History of Religions, as in the name of the scholarly association - the International Association for the History of Religions. ${ }^{16}$ In several respects this research was similar to what was being done in the Old Testament departments, but it included a broader range of cultures and texts. Different versions of phenomenology were part of the picture as well, shaping the study into a comparative as well as a historical enterprise - though few made the daring comparative sweeps that characterized the research of James Frazer and Mircea Eliade. The use of phenomenological and anti-reductionist approaches contributed to keeping the study of religion as a close relative to theology. Existential interests usually drove these approaches; their advocates saw religious phenomena as expressions of common human needs, and regarded religion as basically a positive thing. Sometimes phenomenology came very close to a form of comparative theology. ${ }^{17} \mathrm{~A}$ commonly used example is Eliade's assumption of a transcendental reality lying behind the universal idea of the sacred.

Since these studies were only to a small degree built on the type of approaches and theories that were pursued by most of the past masters, Luther Martin and Donald Wiebe have recently prophetically argued that a scientific study of religion is not likely ever to occur (Martin \& Wiebe 2012, 587-88). Since its heroic origins with Max Müller and Cornelis P. Tiele, they argue, this study has in the main been too deeply infected with religiousness and theology (Martin \& Wiebe 2012, 590), which reflects that 'in both a political and an institutional sense, theology has been, and to a large extent remains, the matrix out of which the academic study of religion has emerged' (Martin \& Wiebe 2012, 590-91). They clearly have a point, even if the picture is more complex and impulses to the study of religion have come from other fields as well, such as Classics, Egyptology and Oriental and Islamic Studies.

The longing reflected in Martin and Wiebe's article for a preferred origin at the cost of what came after easily leads to a specific historical plot: a plot type which implies a fall. This type of historiography is common in Church

16 Michael Stausberg, writing about the different national scholarly associations before the 1990s, says that they all 'have the word "history" in their names, and it seems that there was a broad consensus that an historical approach to religion was what made the field into a discipline, thereby distinguishing it from other scholarly enterprises studying religion' (Stausberg 2008, 309).

17 Timothy Fitzgerald suggests that at one level 'the so-called study of religion (also called the science of religion, religious studies, comparative religion and phenomenology of religion) is a disguised form of liberal ecumenical theology' (Fitzgerald 2000, 6). 
history, for instance when the Protestants looked back to the Gospels and the letters of Paul in their search for an uncontaminated origin, but the plot is also visible in research history. A book edited by William Arnal, Willi Braun and Russell T. McCutcheon, Failure and Nerve in the Academic Study of Religion (2012), takes a similar stand, and offers, according to the publisher, 'the 19th Century founders of the study of religion as a bracing corrective to contemporary timidity'. Here the phase of origin, when the Fathers were alive and kicking, is the Golden Age, which it is impossible or at least extremely difficult to recreate.

\section{Origins Revisited}

The pioneers of the scientific study of religion in the last part of the nineteenth century and the beginning of the twentieth were deeply interested in generative mechanisms and the elementary forms of religion. However, the quest for origins went out of fashion, or rather took new directions. Two prominent scholars, E. E. Evans-Pritchard (1902-1973) and Mircea Eliade (1907-1986), stressed the futility of looking for origins. All the same, both included origin, identity and essence in their work, but in different ways than their predecessors.

In his Theories of Primitive Religion (1965), Evans-Pritchard levelled a devastating critique against the quest for origins in the study of religion: ${ }^{18}$

It is the word genesis on which emphasis is placed. It was because explanations of religion were offered in terms of origins that these theoretical debates, once so full of life and fire, eventually subsided. To my mind, it is extraordinary that anyone should have thought it worthwhile to speculate about what might have been the origin of some custom or belief, where there is absolutely no means of discovering, in the absence of historical evidence, what was its origin. (Evans-Pritchard 1965, 101.)

Evans-Pritchard pointed out the imaginativeness of the theorists, famously branded as the 'If I were a horse' mistake (1965, 24, 47). He compared Frazer, Tylor, and Freud's stories of origin with Rudyard Kipling's Just So Stories, for instance 'How the Camel got his Hump' and 'How the Leopard got his Spots'. All the same, Evans-Pritchard hunts for the real thing, the non-

18 Based on his lectures at the University College of Wales, Aberystwyth in 1962, E. E. EvansPritchard wrote a textbook that was used in universities for at least two decades, Theories of Primitive Religion (1965). 
degenerate variety of religion. In the introduction to his book, he makes a case for the importance of primitive religions, and says that

primitive religions are species of the genus religion and all who have an interest in religion must acknowledge that a study of the religious ideas and practices of primitive people, which are of great variety, may help us to reach certain conclusions about the nature of religion in general, and therefore also about the so-called higher religions or historical and positive religions or the religions of revelation, including our own. (Evans-Pritchard 1965, 1-2.)

He argues that because these religions are independent developments, without historical relations between them, 'they provide all the more valuable data for a comparative analysis aiming at determining the essential characteristics of religious phenomena and making general, valid, and significant statements about them' (ibid.). The most typical religions are, in other words, those that have kept their religious essence and purity. Essence has in his case moved from origin to 'the primitive', which means 'first or earliest of its kind'.

Mircea Eliade warns against the quest for the origin of religion, but was much in favour of studying archaic man, myths of origin and the legendary illo tempore. Tomoko Masuzawa points out the ambiguity in Eliade's treatment of origins in her post-structuralistic book, In Search of Dreamtime: The Quest for the Origin of Religion (1993), where she shows how Eliade moved the quest for origins from the study of religion into religions (Masuzawa 1993, 26-31). According to Eliade, 'every mythical account of the origin of anything presupposes and continues the cosmogony' (Myth and Reality, 1975 [1963], 21). Bruce Lincoln points out that Eliade, like Raffaelle Pettazzoni, had a 'tendency to characterize myth as stories of beginning' (cf. Lincoln 2012, 53). In Eliade's view, religions are about origins and origin: Homo religiosus is obsessed with hierophanies and how the sacred broke into the world.

\section{The New Quest for Origins: Cognition and Evolution}

In her stimulating book, Masuzawa gets most things right, but one thing wrong, due to lack of prophetic power (which one can't blame scholars for not having) (Masuzawa 1993). ${ }^{19}$ In the Introduction she states:

19 Cf. also Preus, who observes: 'The very abundance of contemporary literature about how religions and their study ought to be conceived and organized amounts to evidence of an identity crisis in the field; yet there is little indication today that the question of the cause and origin of religion is, or even should be, a topic of interest' (Preus 1987, xvii). And Preus laments it: 'It is worth reflecting on this remarkable and unfortunate fact' (ibid. xvii). 
It has been some time since the question of the origin of religion was seriously entertained. Today, there is little sign of the matter being resuscitated and once again becoming the focus of the lively debate of old. Looking back upon the bold speculations of their forefathers, contemporary scholars of religion seem to consider themselves to be in a new phase of scholarship, having learned, above all, not to ask impossible questions. Reputedly, those grand old ideas - the so-called theories of the origin of religion - were conceived by the powerful Victorian imagination in the lacunae of concrete data, and it therefore should be hardly surprising that they turned out to be stillborn. (Masuzawa 1993, 1.)

More than twenty years have passed since these words were written, and the contemporary focus on the evolution of mind and the cognitive turn in the humanities have made scholars look back to an even older origin than the founding fathers did in the late 19th century, that is, to the evolution of the human species and to the development and processes of its brain. In other words, origin is now approached via cognitive science, evolutionary biology and cultural anthropology. In these studies, beginnings in time are sometimes fused with origins in the mythic past of Deep history.

Aaron W. Hughes observes that contemporary theories of religion give the impression that 'recent trends in thinking about the origin and persistence of religion [... have] largely migrated out of the humanities into the natural and behavioural sciences, even if such theorizing is still largely carried out in Religious Studies departments' (Hughes 2010, 293-4). This is a pertinent observation. Earlier it was mainly social scientists that furnished the discipline with theories of origin; now the inspiration comes from the natural sciences as well (Pals 2006, 304).

In one of the classics in this new field, Pascal Boyer's Religion Explained: The Evolutionary Origins of Religious Thought (2001), ${ }^{20}$ the author discusses the general characteristics of religion, but he also touches on the more specific origin of religion, and points out that we 'should not be surprised that the souls of the dead or their "shadows" or "presence" are the most widespread kind of supernatural agent the world over' (Boyer 2001, 227). ${ }^{21}$ In a recent article, Justin L. Barrett points both to Pascal Boyer and to Paul Bloom: 'Bloom's and Boyer's accounts help explain why the idea that

20 The book has also appeared under the title, Religion Explained: The Human Instinct That Fashions Gods, Spirits and Ancestors. London: William Heinemann, 2001.

21 The first International Conference on the Evolution of Religion was held in 2007 (Bublbulia et. al. 2008). 
some human spirit survives death and continues to act in the world may be the most widespread and oldest religious concept' (Barrett 2011, 215).22 Barrett suggests that the Darwinian understanding of evolution raises four alternatives of when and how religion might have risen. In terms of origin in time, Barrett favours the Concurrence Hypothesis: human beings and religion appear at the same time; and he suggess that what makes us 'behaviourally modern humans is the same thing that makes us religious' $(2011,207)$.

So one contemporary solution to the quest for the origin of religion - and there are several - is in the depths of the Deep history of human beings when man/woman became homo religiosus in the same moment as s/he became homo sapiens sapiens ca. 200000 years ago. ${ }^{23}$ In line with a similar Deep history perspective, animism connected to ancestors is sometimes seen as the oldest and most widespread variety of religion.

This might sound a little bit simplistic. It is not far removed from the 'pourquoi stories' or 'Just So Stories' so devastatingly criticized by EvansPritchard, and it has, arguably, something in common with Edward B. Tylor's old ideas in Primitive Culture (1871). Bruce Lincoln argues that

use of comparison to reconstruct (i.e. hypothesize) a remote past era for which no direct evidence survives is an invitation to project one's favoured fantasies into a relatively blank screen. That screen, however, is distorting and prejudicial, as it invests such projectors with the prestige of 'origins' (e.g. 'our most ancient traditions', 'the world of our ancestors', 'the archaic', 'the primordial'). (Lincoln 2012, 122-3.)

When a cognitive approach is used to revisit the issue of religious origin, the purpose is to identify the generative mechanisms of religion (cf. Anttonen 2002). In Veikko Anttonen's view, the origin of religion 'is not an issue of historical specificity. It cannot be solved by attempts to reconstruct a location in a specific historical moment at which the human capacity for religion is postulated to have first emerged' (Anttonen 2002, 25). Instead, the cognitive scholar asks about the evolution of the conceptual capacities of humans, and in this quest a wide area of advances made in, for instance,

22 In the same article, Barrett identifies the one common factor that makes proto-religions into full-blown religions: It is meta-representations, 'the ability to form mental representations of mental representation' (Barrett 2011, 205).

23 Armin Geertz has recently ventured a hypothesis that pushes the beginning of religion even further back, to Homo heidelbergensis, 4-600 000 years ago (Geertz 2013a \& 2013b). 
linguistics, cognitive psychology, ethology, computer science, cybernetics etc. are referred to in the quest for the generative mechanisms of religion.

The cognitive science of religion has problematic sides, however (Rydving 2008). ${ }^{24}$ To see the new theories about religion, cognition and evolution as simplistic is somewhat unfair. Those who have their background in a scientific study of religion and promote cognitive theories are in the main aware that religion is a discursive phenomenon and that it has several dimensions. ${ }^{25}$ The cultural and historical dimensions are sometimes also included in the study, which contributes to make this research more promising. ${ }^{26}$ When, as pointed out above, the classical theoreticians in the field, according to Pals, define religion in relation to superhuman beings, it is clearly interesting to study this type of universal human idea - belief in and communication with superhuman beings - in relation to cognition and human evolution. In a similar way as earlier with theology, the new naturalistic explanations of religion are now sometimes seen as a new significant other in relation to more traditional studies of religion (cf. Sutcliffe 2008, 108).

\section{Origin, Theology and Identity}

This article does not question the value of contemporary approaches to religion built on cognitive studies and evolutionary biology, which are developing into a whole new research field, but asks why these approaches have become so prominent today. Why does the contemporary study of religion need the metaphysical boost of origins, sometimes combined with more than a nod to the nineteenth century and the founding fathers? What is at stake? Why this renewed quest for origins in the study of religion - a quest now mainly oriented towards cognitive studies, but also towards Deep history?

It is reasonable to see the interest in the long lines of human history and universal patterns of human cognition in line with prevailing tendencies in

24 Håkan Rydving has pointed out some of these problematic aspects. Among them he mentions a confrontational style, hegemonic claims, presenting religion as an entity of its own kind and analysing only some of its elements (pars pro toto), counterintuitivity (counterintuitive for whom?), the problematic analogy between religion and language, insufficient cross-cultural empirical evidence, and inadequate hypothesis-testing (Rydving 2008).

25 Boyer, for instance, points out the problem with thinking 'that we can explain the origin of religion by selecting one particular problem or idea or feeling and deriving the variety of things we now call religion from that unique point' (Boyer 2001, 36, 379; see also Geertz 2013a, 2).

26 Today there are attempts to forge a bridge between the new and the old research fields with an emphasis on the significance of culture for human cognition (Geertz 2013b; Sørensen 2004; cf. also Sutcliffe 2008). The new journal, Journal of Cognitive Historiography, is a witness to the interaction between cognitive studies, history, historiography and archaeology. 
the study of religion. Large-scale comparative studies and universal claims have been expressed in different ways, from James Frazer and the evolutionary paradigm to Mircea Eliade and the phenomenological paradigm, but they have always in one way or other been a very visible part of the discipline. ${ }^{27}$

Strong impulses come, as already mentioned, from recent developments in science. Just as the quest for the origin of religion in the late nineteenth century was dependent on evolutionary theory, most famously expressed by Charles Darwin in The Origin of the Species (1859), the new quest for religious origin is dependent on scientific achievements and recent breakthroughs in fields such as neuroscience, genetics and studies of human cognition, but also in archaeology and evolutionary ecology.

The quest for origins, be it in cognitive studies or in evolutionary history, might further be seen as dependent on contemporary processes of globalization. Globalization implies, in the words of Roland Robertson, seeing the earth as 'one single place' (Robertson 1992, 281). Globalization breeds a wish to take in the human condition in a single sweep, and therefore also to try to get the full picture of human history from its evolutionary beginnings to the present. It creates an impulse to write world history or Deep history or even Big history. This impulse is carried over into the study of religion, as was to be expected, because this study has always had a historical dimension as well as a strong wish to view religion synoptically and in a comparative perspective, seen, for instance, in the works of James Frazer and Mircea Eliade. So, in the present situation, where there are strong cultural impulses that work in the direction of writing global history and searching for human origins, these impulses are also reflected in the study of religion.

In the global situation, there is further a renewed general interest in religion, which has resulted in religion also being studied in university departments other than those devoted to scientific or theological studies of religion, such as cultural studies, sociology and media. The quest for origins might then be seen as an attempt to establish dominant control over the field, not only in relation to other disciplines, but also as an effort to establish cognitive studies as a superior approach within the scientific study of religion.

27 In addition to specific reasons why the quest for origins has been prominent in the study of religion, there are also more general reasons why humans search for origins. Veikko Anttonen aptly points out that awareness of causes and origins makes it possible for humans to embrace abstract notions such as, for instance, Identity, Ethnicity, Freedom etc., and 'reflect upon the properties on which essences of things are based and by means of which they are preserved in spite of changes and transformations, whether biological, historical or sociocultural' (Anttonen 2002, 26). 
In addition to a permanent interest in universal patterns, the contemporary global situation, current breakthroughs in science, and a wish to control the field, the quest for origins in the study of religion answers a basic need, because it relates to a perceived lack of disciplinary identity. One driving force in the new quest for origins seems to be the same today as it was more than a hundred years ago, the continuous struggle to be different from theology. Since religion is preoccupied with divine origins, a secular study of religion is preoccupied with natural origins. Aaron Hughes has suggested that 'scientific' attempts to uncover religious origins 'is either an attempt to understand why people are still religious today [...] or to explain religion with the aim of explaining it away' $(2010,302)$ (Italics are in the original). The search for the origins of religion in the scientific study of religions is still part of a struggle to construct religion in a radically different way from how it is constructed by theology and, for that matter, from how it is experienced by religious people (cf. Johansen 2010).

The new interest in origins implies not only a sense of the lack of distinctive disciplinary identity, but also dissatisfaction with the sort of identity that does exist, and an attempt to create a stronger and more specific identity. Such a shift of identity is, for instance, reflected in the construction of a special scholarly association in 2006, the International Association for Cognitive Science of Religion. The wish to go back to disciplinary beginnings and make a fresh start is sometimes made explicit. In the introduction to the first issue of Journal for the Cognitive Science of Religion, Dimitris Xygalatas and Ryan McKay write:

Of course, scientific interest in the mental underpinning of religion is not new. It dates back at least to the beginnings of disciplines like psychology, sociology, and anthropology. However, after a long period of drought brought on by the neglect of mental processes during the reign of culturology, behaviourism, and the sui generis view of religion and culture, the cognitive revolution of the 1950s provided the rain that germinated the seed. (Xygalatas \& McKay 2013, 2.)

In this narrative, the fall of the past is followed by the ascent of the present. In this way the historiography of the cognitive science of religion is constructed as a fall-and-rise narrative (cf. Zerubavel 2003, 19).

Because the Cognitive Science of Religion is a new discipline it needs to develop a new identity and to distance itself from the immediate past. As Michel de Certeau puts it: 'Historical discourse makes a social identity explicit, 
not so much in the way it is 'given' or held as stable, as in the way it is differentiated from a former period or another society' (Certeau 1988, 45). In a recently published edited volume, leading scholars in the Cognitive Study of Religion (CSR) were invited to comment on classical theories, which here means traditional social theories, and to relate them to the present (Xygalatas \& McCorkle 2013). ${ }^{28}$ The volume is an explicit attempt to give CSR ancestors, because, according to the editors, 'we realized that the cognitive science of religion was seen by most scholars of religion as a new and alien field, unrelated to the humanities and the social sciences' (Xygalatas \& McCorkle 2013 , 9). The intention was therefore to show 'that CSR is not the product of parthenogenesis within the study of religion' (Xygalatas \& McCorkle 2013, 9). An answer to the suspicion of being the product of parthenogenesis is now, as always, a return to old fathers. ${ }^{29}$

\section{The Turtles and the Elephant in the Room}

In this article the father-metaphor has been applied for those who are singled out as generators, ancestors and models. The founding fathers are situated at the origin and they point to origins. Fathers are symbols, or, perhaps, in the case of Max Müller and his successors, they represent the research history in condensed form. They are sometimes venerated at a distance, like Max Müller, but sometimes they also end up being heavily criticized, which has been the fate of Mircea Eliade. In Freud's myth of the origin of religion, the father is killed and eaten, resulting in his continuous presence. Tomoko Masuzawa describes the 'ambiguity - or, perhaps more properly speaking, the ambivalence - permeating the scene of incomplete burial of the classical masters' (Masuzawa 1993, 4).

Fathers may be an inspiration, especially in the way that Pascal Boyer concludes in relation to Claude Lévi-Strauss: 'Scientific ancestors should be interestingly wrong in their conclusions and quite admirable in their assumptions' (Boyer 2013, 175). Some ancestors are still admired, for instance, Émile Durkheim and Max Weber, whose works continue to gener-

28 The ancestors included in this book are Edward B. Tylor, Karl Marx, Émile Durkheim, Max Weber, Bronislaw Malinowski, Sigmund Freud, Jean Piaget, William James, Claude LéviStrauss, and Clifford Geertz.

29 One might argue that in the case of CSR the attempt to change identity is in some ways more radical than what happened in the last part of the 19th century when the nontheological study of religion was created, since CSR has sometimes been conceived of as an opting-out from the humanities and a transfer to the natural sciences, with laboratories and experiments. 
ate new questions and influence cutting-edge research. The complexity in their approaches and the reflexivity in their descriptions contribute to their continued presence in the study of religion.

The keywords here are indeed complexity and reflexivity. Religious communication is dynamic and changing, just as our understanding of this communication is. The scientific study of religion applies a wide range of types of sources and combines many different methodological and theoretical approaches. This is not evidence of a lack of disciplinary identity, but rather witness to a complex identity. In addition, research in religion takes and should take a multi-disciplinary form, and include cross-disciplinary collaboration. Instead of fully accepting that religion is a complex phenomenon, and in line with this, that the scientific study of religion by necessity must have a complex identity as well, there is, however, a cry for simple solutions. Such simple solutions are offered as a return to the fathers, roots and a quest for origins, and, not least, in treating theology as the significant other.

Constructing theology as the significant other overlooks the fact that theology is a much more complex entity that is usually recognized in nontheological circles. The historical and philological approaches to ancient texts and artefacts raise several of the same challenges as the study of biblical texts and Church History; here, therefore, is common ground between the theological disciplines and the historical study of religion.

Perhaps it would be fruitful to reflect on the real influences on one's own research. The small research stories of individuals and groups often look different from the grand narrative which is regularly told as a matter of routine to new students in the field. Perhaps there are even significant mothers in these stories? One could also ask if the scientific study of religion has been such a rich discipline, since - when all is said and done - the fathers have not had too much influence on what actually took place in the development of the discipline. ${ }^{30}$

There are at least two major challenges for the scientific study of religion. One is that grand-scale comparative studies and universal claims need to be matched by small-scale studies of religion on the ground. To develop theories and models suited to study religion on this level, whether we call it 'lived' religion 'everyday' religion or 'vernacular' religion, is essential (Sutcliffe 2013; Sutcliffe \& Gilhus 2013). Here as well it is important to keep

30 This article is in the main based on Anglophone scholars; there are alternativee stories of origin in different countries, and they deserve more attention. One example is Wilhelm Schenke and the origin of the study of religion in Norway, which is briefly referred to above. 
complexity in the study, and to manage to pursue different approaches at the same time.

Another challenge is not to eliminate the object of study by denying the existence of religion understood as communication with culturally postulated superhuman beings. The prophesy that the preoccupation with origins will end has proved to be wrong. I venture to offer a second prophesy, and not a very daring one: Religion has come to stay. This implies that we will never go out of business. A prerequisite for continuous relevance is to embrace complexity and reflexivity, not be stuck in the dependency on theology, and decline from deconstructing the concept of religion in such a way that nothing is left.

Bibliography

\section{Anttonen, Veikko}

2002 Identifying the Generative Mechanisms of Religion: The Issue of Origin Revisited. - Ilkka Pyysiäinen \& Veikko Antonen (eds), Current Approaches in the Cognitive Science of Religion, 14-37. London: Continuum.

\section{Aristotle}

1965 [1927] Poetics, translated by W. Hamilton Fyfe (The Loeb Classical Library). London/Cambridge MA: William Heinemann/Harvard University Press.

\section{Arnal, William \& Willi Braun}

2012 The Irony of Religion. - William Arnal \& Willi Braun \& Russell T. McCutcheon (eds), Failure and Nerve in the Academic Study of Religion, 230-38. Sheffield: Equinox.

Arnal, William \& Willi Braun \& Russell T. McCutcheon (eds)

2012 Failure and Nerve in the Academic Study of Religion. Sheffield: Equinox.

Barrett, Justin L.

2011 Metarepresentation, Homo Religiosus, and Homo Symbolicus. - Christopher S. Henshilwood \& Fransesco d' Errico (eds), Homo Symbolicus: The Dawn of Language, Imagination and Spirituality, 205-24. Amsterdam/ Philadelphia: John Benjamins Publishing Company.

\section{Boyer, Pascal}

2001 Religion Explained: The Evolutionary Origins of Religious Thought. New York, NY: Basic Books. 
2013 Explaining Religious Concepts: Lévi-Strauss the Brilliant and Problematic Ancestor. - Dimitris Xygalatas \& William W. McCorkle Jr. (eds), Mental Culture: Classical Social Theory and the Cognitive Science of Religion, 164-75. Durham, UK: Acumen.

Bulbulia, Joseph et al. (eds)

2008 The Evolution of Religion: Studies, Theories and Critiques. Santa Margarita, CA: Collins Foundation Press.

\section{Certeau, Michel de}

1988 [1975] The Writing of History. New York, NY: Columbia University Press.

\section{Darwin, Charles}

1859 On the Origin of the Species by Means of Natural Selection or the Preservance of Favoured Races in the Struggle for Life. London: John Murray.

\section{Eliade, Mircea}

1975 [1963] Myth and Reality, New York, NY: Harper.

\section{Epiphanius}

2009/2013 The Panarion. Translated by Frank Williams. Leiden: Brill.

Evans-Pritchard, E. E.

1965 Theories of Primitive Religion. Oxford: Clarendon Press.

\section{Fitzgerald, Timothy}

2000 The Ideology of Religious Studies. New York, NY: Oxford University Press.

\section{Foucault, Michel}

1980 Nietzsche, Genealogy, History. - Donald F. Bouchard (ed.), Language, Counter-Memory, Tradition. Selected Essays and Interviews, 139-64. Ithaca, NY: Cornell.

\section{Freud, Sigmund}

1913 Totem und Tabu. Leipzig: Heller.

\section{Geertz, Armin}

2013a Introduction. - Armin Geertz (ed.), Origins of Religion, Cognition and Culture, 1-16. Durham, UK: Acumen.

$2013 \mathrm{~b}$ Whence religion? How the brain constructs the world and what this might tell us about the origin of religion, cognition and culture. Armin Geertz (ed.), Origins of Religion, Cognition and Culture, 17-70. Durham, UK: Acumen.

\section{Gilhus, Ingvild Sælid \& Knut Jacobsen}

2014 From the History of Religions to the Science of Religion. - Temenos: Nordic Journal of Comparative Religion, 50 (1), 63-78. 
Harnack, Adlof von

1906 Reden und Aufsätze, volume 2. Giessen: Töpelmann.

\section{Hughes, Aaron W.}

2010 Science Envy in Theories of Religion. - Method and Theory in the Study of Religion 22, 293-303.

2012 Abrahamic Religions: On the Uses and Abuses of History. Oxford: Oxford University Press.

\section{Hume, David}

1757 The Natural History of Religion. (edited with an introduction by H. E. Root). London: Adam \& Charles Black.

Johansen, Birgitte Schepelern

2010 Adskillelsens logic. En undersøgelse af sekulære kategoriseringer af religion i akademisk praksis. Doktorgradsavhandling Københavns universitet. Det humanistiske fakultet.

\section{Lincoln, Bruce}

2012 Gods and Demons, Priests and Scholars: Critical Explorations in the History of Religions. Chicago: University of Chicago Press.

\section{Martin, Luther \& Donald Wiebe}

2012 Religious Studies as a Scientific Discipline: The Persistence of a Delusion. - Religio: Revue pro religionistiku 20, 1, 9-18; Journal of the American Academy of Religion 80, 3, 587-97.

\section{Masuzawa, Tomoko}

1993 In Search of Dreamtime: The Quest for the Origin of Religion. Chicago \& London: The University of Chicago Press.

\section{McCutcheon, Russell T.}

2001 Critics not Caretakers. Redescribing the Public Study of Religion. Albany, NY: State University of New York Press.

\section{Müller, F. Max}

1872 Lectures on the Science of Religion. New York, NY: Charles Scribner and Company.

\section{Pals, Daniel, L.}

1996 Seven Theories of Religion. New York, NY: Oxford University Press.

2006 Eight Theories of Religion. New York, NY: Oxford University Press.

\section{Paul, Herman}

2011 Hayden White (Key Contemporary Thinkers). London: Polity Press.

\section{Preus, J. Samuel}

1987 Explaining Religion: Criticism and Theory from Bodin to Freud. New Haven, CN: Yale University Press. 


\section{Robertson, Roland}

1992 Globalization: Social Theory and Global Culture. London: Sage.

\section{Rydving, Håkan}

2008 A Western Folk Category in Mind? - Temenos: Nordic Journal for the Study of Religion, 44 (1), 73-99.

\section{Schencke, William}

1913 'Det teologiske fakultet bør sløifes', Tidens tegn (Newspaper)

Sharpe, Eric J.

1975 Comparative Religion. A History. London: Duckworth.

\section{Smail, Daniel Lord}

2009 Deep History and the Brain. Berkeley and Los Angeles, CA: University of California Press.

\section{Stausberg, Michael}

2007 The study of religion(s) in Western Europe (I): Prehistory and history until World War II. - Religion 37, 294-318.

2008 The study of religion(s) in Western Europe (II): Institutional developments after World War II. - Religion 38, 305-18.

2009 The study of religion(s) in Western Europe III: Further developments after World War II. - Religion 39, 261-82.

\section{Sutcliffe, Steven J.}

2008 'Two Cultures' in the Study of Religion? A Response to Håkan Rydving. - Temenos: Nordic Journal for the Study of Religion, 44 (1), 101-10.

2013 New Age, world religions and elementary forms. - Steven Sutcliffe \& Ingvild Sælid Gilhus (eds), New Age Spirituality: Rethinking Religion, 17-34. Durham, UK: Acumen.

\section{Sutcliffe, Steven \& Ingvild Sælid Gilhus}

2013 Introduction: 'All mixed up' - thinking about religion in relation to New Age spiritualities. - Steven Sutcliffe \& Ingvild Sælid Gilhus (eds), New Age Spirituality: Rethinking Religion, 1-16. Durham, UK: Acumen.

\section{Sørensen, Jesper}

2004 Religion, Evolution, and an Immunology of Cultural Systems. - Evolution and Cognition 10 (1), 61-73.

\section{Tilley, Terence $W$.}

1991 Polemics and Politics in Explaining Religion. - The Journal of Religion $71(2), 242-54$.

Tylor, Edward B.

1871 Primitive Culture. 2 volumes. London: J. Murray. 
White, Hayden

1972 What is a Historical System? - Allen D. Breck \& Wolfgang Yourgrau (eds), Biology, History and Natural Philosophy, 233-42. New York and London: Plenum Press.

1973 Metahistory: The Historical Imagination in Nineteenth Century Europe. Baltimore, MD: John Hopkins University Press.

Xygalatas, Dimitris \& William W. McCorkle Jr. (eds)

2013 Mental Culture: Classical Social Theory and the Cognitive Science of Religion. Durham, UK: Acumen.

Xygalatas, Dimitris \& William W. McCorkle Jr.

2013 Introduction: social minds, mental cultures - weaving together cognition and culture in the study of religion. - Dimitris Xygalatas \& William W. McCorkle Jr. (eds), Mental Culture: Classical Social Theory and the Cognitive Science of Religion, 1-10. Durham, UK: Acumen.

Xygalatas, Dimitris \& Ryan McKay

2013 Announcing the Journal for the Cognitive Science of Religion. - Journal for the Cognitive Science of Religion 1 (1), 1-4.

\section{Zerubavel, Eviatar}

2003 Time Maps: Colleective Memory and the Social Shape of the Past. Chicago and London: University of Chicago Press. 